\title{
Preparation of Thin and Dense Lanthanum Cobaltite Coating on Porous Tubular Alumina Supports by Electrophoretic Deposition
}

\author{
Hideyuki NEGISHI, Norio OSHIMA, ${ }^{*}$ Kenji HARAYA, Keiji SAKAKI, Toru IKEGAMI, Yasushi IDEMOTO, ${ }^{*}$ \\ Nobuyuki KOURA* and Hiroshi YANAGISHITA
}

Research Institute for Innovation in Sustainable Chemistry, National Institute of Advanced Industrial Science and Technology (AIST), AIST Central 5-2, 1-1-1, Higashi, Tsukuba-shi, Ibaraki 305-8565

*Faculty of Science and Technology, Tokyo University of Science, 2641, Yamazaki, Noda-shi, Chiba 278-8510

\author{
泳動電着法による管状多孔質アルミナ基板上への \\ ランタンコバルタイト緻密酸化物薄膜の作製

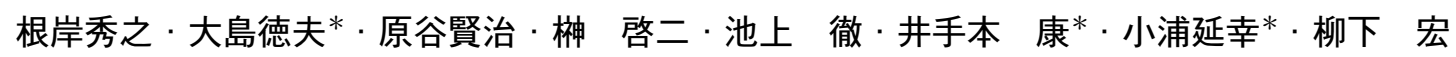 \\ 産業技術総合研究所環境化学技術研究部門，305-8565 茨城県つくば市東 1-1-1 つくば中央 5-2 \\ *東京理科大学理工学部, 278-8510 千葉県野田市山崎 2641
}

\begin{abstract}
The electrophoretic deposition (EPD) process is one of several ceramic powder assembling technologies using a simultaneous colloidal process and electrochemical driving force. For the further development of the EPD technique, the possibility and the usefulness of preparing a thin and dense ceramic coating on non-electronically conductive porous tubular ceramics using the EPD technique was investigated. $\mathrm{La}_{0.8} \mathrm{Sr}_{0.2} \mathrm{Co}_{0.8} \mathrm{Sr}_{0.2} \mathrm{O}_{3-\delta}$ (LSCF) was used as the deposition material and a porous alumina tube was used as the deposition substrate. Methanol (MeOH) was suitable as a dispersing medium for the LSCF powder. LSCF particles were positively charged in MeOH. For the fabrication of a uniform EPD layer, the cathode was placed in a porous alumina tube. The insides of the porous alumina tubes were filled with $\mathrm{MeOH}$ and the cathode did not make contact with the EPD bath. A $30 \mu \mathrm{m}\left(200 \mathrm{~g} / \mathrm{m}^{2}\right)$ thick uniform LSCF powder coating was obtained by EPD at $100 \mathrm{~V}$ for $10 \mathrm{~min}$. After sintering at $1500^{\circ} \mathrm{C}$ for $5 \mathrm{~h}$, a $20 \mu \mathrm{m}$ dense membrane was obtained.
\end{abstract}

[Received August 18, 2005; Accepted October 20, 2005]

Key-words : Electrophoretic deposition, Lanthanum cobaltite, Mixed conductor, Thin coating, Dense coating, Porous alumina, Tubular, Methanol

\section{Introduction}

Recently, a new technology involving the systematic arrangement of size-controlled fine particles in two or three dimensions has attracted increasing attention as a ceramic powder coating technology. ${ }^{1)-3)}$ The wet-process fabrication is especially attractive because of its mass productivity and low cost. As for the systematic arrangement of particles on a substrate, it has become interesting to control the interaction of the particle-particle and/or particle-substrate in the colloidal solution based on the simultaneous colloidal processing and externally added electrical field, gravitation field etc.

The electrophoretic deposition (EPD) process is one of several ceramic powder assembling technologies using a simultaneous colloidal process and electrochemical driving force. This process is very simple; the dispersed and charged particles in a solvent migrate to an electrode substrate under a certain potential gradient using a DC power source. The EPD technique has some advantages compared to the other fabrication techniques especially for decreasing the fabrication costs and structural flexibility of the substrates. Therefore, the EPD technique has been widely evaluated as a ceramic processing technique for a variety of technical applications, e.g., electrodes, solid oxide fuel cells (SOFCs), nanostructured materials and coatings for electronic, biomedical, optical, catalytic and electrochemical applications. ${ }^{1)}$ The EPD technique has been investigated for the fabrication of thin electrolyte materials such as yttria-stabilized zirconia (YSZ), scandia-stabilized zirconia (ScSZ), gadolinium-doped ceria (CGO) and so on, on porous cathodes or anodes such as lanthanum manganate,
NiO-ScSZ and NiO-YSZ, for the SOFCs. ${ }^{4)-9)}$ Based on these reports, the feasibility of the EPD technique has been confirmed.

On the other hand, mixed oxygen ionic and electronic conducting oxides have been proposed as oxygen-permeable membranes for high-purity oxygen generators and chemical reactor applications. Perovskite-type oxides $\mathrm{La}(\mathrm{A}) \mathrm{Co}(\mathrm{Fe}) \mathrm{O}_{3-\delta}(\mathrm{A}=$ $\mathrm{Sr}, \mathrm{Ba}, \mathrm{Ca})$ with a high ionic conductivity and prevailing electronic conductivity represent one of the most promising groups of mixed conductors. ${ }^{10)-15)}$ Upon applying an oxygen partial pressure across a membrane made of a mixed conducting oxide, an oxygen permeation flux occurs under $900^{\circ} \mathrm{C}$. The oxygen permeation process consists of oxygen exchanges between the gas/solid interface, and the counter diffusion of oxygen ions and electronic species in the bulk of the membrane. ${ }^{16)}$ For enhancement of the oxygen permeation flux, a thin and dense membrane prepared on a porous and heat-resistant substrate was required. The EPD technique is considered as one of the suitable methods for the preparation of such a membrane, because this method can easily control the coating thickness to less than $50 \mu \mathrm{m}$. On the other hand, porous alumina is expected to be a lower cost substrate with a good heat resistance. Generally, an electronically conductive substrate as a function of the electrode is required for the EPD method. However, alumina is a non-electronic conducting material. Therefore, an alumina substrate cannot be used as a deposition electrode. There is an example that the EPD method was applied to a polymer membrane which was not an electrode. ${ }^{17)}$ However, the deposition substrate in this case is 
not a ceramic material. As another example, the fabrication of a ceramic membrane filter made by EPD onto porous ceramic substrates was reported, but the target of their study was not to obtain a gas tight membrane. ${ }^{18)}$ In addition, the fabrication of a dense YSZ coating made by EPD on a porous NiO-YSZ disk, whose one side was coated by graphite spray as an electrode, was reported..$^{9)}$ However, their fabrication process includes an electrode coating step, and their spray coating method seems to be difficult to be applied onto such places as the inside of tubular substrates. Therefore, for the development of the EPD technique, an investigation of the EPD onto a porous tubular substrate which does not have a good electronic conductivity and a thin and gas tight layer after the sintering process is necessary.

In this study, we investigated the possibility and the usefulness of preparing thin and dense mixed conducting oxide layers on a porous tubular alumina substrate using the EPD technique. $\mathrm{La}_{0.8} \mathrm{Sr}_{0.2} \mathrm{Co}_{0.8} \mathrm{Sr}_{0.2} \mathrm{O}_{3-\delta}$ (LSCF) was used as the mixed conducting oxide. In particular, two subjects are the focus of this study. One is the EPD of oxide particles on porous tubular alumina substrates, because a porous alumina substrate does not work as an electrode. The other one is controlling the coating thickness to less than $50 \mu \mathrm{m}$ by EPD on porous substrates.

\section{Experimental}

\subsection{Preparation of LSCF powder}

$\mathrm{La}_{0.8} \mathrm{Sr}_{0.2} \mathrm{Co}_{0.8} \mathrm{Fe}_{0.2} \mathrm{O}_{3-\delta}$ (LSCF) was prepared by a solid state reaction method. The starting materials were $\mathrm{La}_{2} \mathrm{O}_{3}$ (Wako Pure Chemical Co., 99.5\%), $\mathrm{SrCO}_{3}$ (Wako Pure Chemical Co., 99.9\%), CoO (Wako Pure Chemical Co., 90\%) and $\mathrm{Fe}_{2} \mathrm{O}_{3}$ (Wako Pure Chemical Co., 99.9\%). The ball-milled powder mixtures of the starting materials, uniaxially pressed into pellets at a pressure of $45 \mathrm{MPa}$, were calcined at $1400^{\circ} \mathrm{C}$ for $5 \mathrm{~h}$. in air. The ball-milling and the calcinations were repeated three times. The density of the synthesized LSCF powder was measured using a pycnometer. The crystal structure analysis was carried out by X-ray diffraction (XRD, MAC Science Co., Ltd, MXP3). The morphology was observed using a scanning electric microscope (SEM, Hitachi Co., Ltd., S-800). The particle size distribution was measured by an electrophoretic light scattering spectrometer (Otsuka Electronics Co., Ltd., ELS-8000) at $25^{\circ} \mathrm{C}$. The dispersion stability of the LSCF powder was evaluated using a TURBISCAN Lab/thermo (Eko Instruments Co., Ltd.). The analyzed dispersion is placed in a cylindrical glass cell. The light source is an electro luminescent diode with the wavelength in the near infrared $\left(\lambda_{\text {red }}=880 \mathrm{~nm}\right)$. The profile of the transmitted light flux was provided as a function of the sample height (in $\mathrm{mm}$ ) and the specified times.

\subsection{Electrophoretic deposition}

The zeta potential and the electrophoretic mobility of the LSCF particles were measured by an electrophoretic light scattering spectrophotometer (Otsuka Electronics, ELS-8000) at $25^{\circ} \mathrm{C}$. Methanol, ethanol, 1-propanol or 2-propanol (Wako Pure Chemical Co., Ltd.) were used as the EPD bath. The fundamental EPD bath was prepared as follows. The concentration of the EPD baths was $10 \mathrm{~g} / \mathrm{L}(1.5 \mathrm{~g} / 150 \mathrm{ml})$. The LSCF powder baths were dispersed by ultrasonic vibration for $10 \mathrm{~min}$. Stainless steel tubes (SUS304, $\phi_{\mathrm{OD}}=10 \mathrm{~mm}, L=50$ $\mathrm{mm}, t=0.8 \mathrm{~mm})$ and porous alumina tubes $\left(\phi_{\mathrm{OD}}=10 \mathrm{~mm}\right.$, $L=50 \mathrm{~mm}, t=1.0 \mathrm{~mm}$, average pore size is $0.52 \mu \mathrm{m}$, porosity is $32 \%$; Noritake Co., Ltd.) were used as the deposition substrates, and a stainless steel mesh (SUS304, $\phi_{\mathrm{OD}}=30 \mathrm{~mm}, L=$ $50 \mathrm{~mm}, 300 \mathrm{mesh}$ ) was used as the counter electrode. The dis-

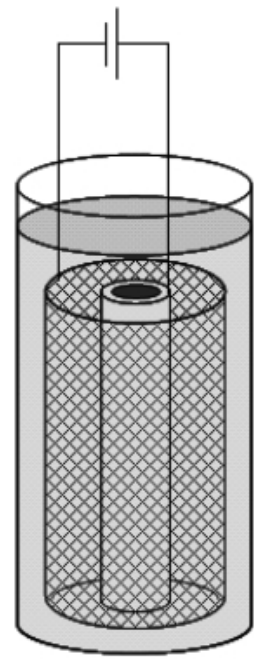

(a)

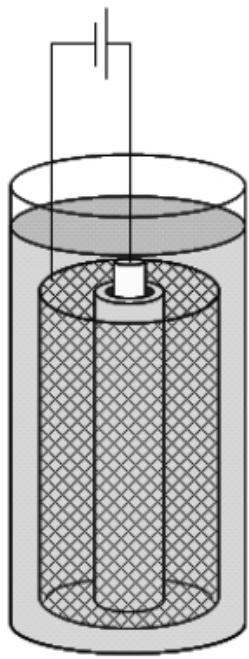

(b)
Fig. 1. Fundamental cell configuration of EPD for the fabrication of LSCF coating. (a) tubular substrate is electrode, (b) tubular substrate is not electrode.

tance between the two electrodes was $c a .10 \mathrm{~mm}$. The substrate (electrode) and counter electrode were placed as shown in Fig. 1. Figure 1 (a) is when the tubular substrate is the electrode and Fig. 1 (b) is when it is not the electrode. In the EPD process, DC voltages of $25-300 \mathrm{~V}$ were applied using a DC power source (Takasago Co., Ltd., TP0360-022D). For the alumina substrates, stainless steel tubes (SUS304, $\phi_{\mathrm{OD}}=$ $3 \mathrm{~mm}, L=50 \mathrm{~mm}, t=0.6 \mathrm{~mm}$ ) were inserted into the alumina substrate because it does not have an electronic conductivity. After EPD, the electrophoretically deposited porous tubular alumina substrate was dried under ambient conditions, subsequently sintered at $1400-1600^{\circ} \mathrm{C}$ for $6 \mathrm{~h}$. The tubular membrane was observed using a confocal laser microscope (KEYENCE, VK-9500) and a scanning electron microscope (SEM, Hitachi Co., Ltd., S-800).

\subsection{LSCF powder}

\section{Results and discussion}

The peaks of $2 \theta=23.4^{\circ}(100), 33.3^{\circ}$ (110), $40.8^{\circ}$ (111), $47.5^{\circ}(200), 53.7^{\circ}(210), 58.9^{\circ}(211), 69.6^{\circ}(220)$ and $79.1^{\circ}$ (310), which matched well with those of the perovskite phase, were observed from the powder XRD pattern as shown in Fig. 2. Therefore, the synthesis of LSCF was confirmed by a solid state reaction method. The average particle diameter of the ground LSCF powder is approximately $500 \mathrm{~nm}$ and the powder size distribution is 200 to $900 \mathrm{~nm}$ as shown in Fig. 3. The estimated density of the LSCF powder measured by a pycnometer is $c a .6 .73\left[\mathrm{~g} / \mathrm{cm}^{3}\right]$ at $25^{\circ} \mathrm{C}$. Figure 4 shows an SEM photograph of the LSCF powder. The shape of each particle is not smooth, but sharp like a fragment.

3.2 Zeta potential and electrophoretic mobility of LSCF powder

As for the dispersion characteristic and electrophoretic property of the LSCF particles in various solvents, the zeta potentials and the electrophoretic mobility were measured. Here, the zeta potential is related to the charging in the solvent, and the electrophoretic mobility is related to the properties of the solvent as shown in Eq. (1).

$$
v / E=\varepsilon_{\mathrm{r}} \varepsilon_{0} \zeta / \eta
$$




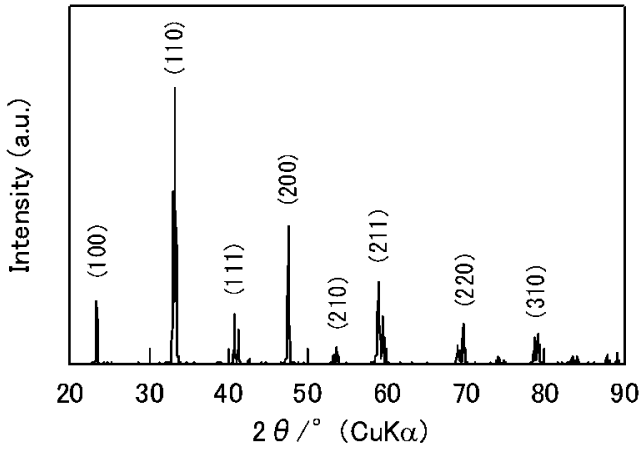

Fig. 2. XRD pattern of $\mathrm{La}_{0.8} \mathrm{Sr}_{0.2} \mathrm{Co}_{0.8} \mathrm{Fe}_{0.2} \mathrm{O}_{3-\delta}$ powder.

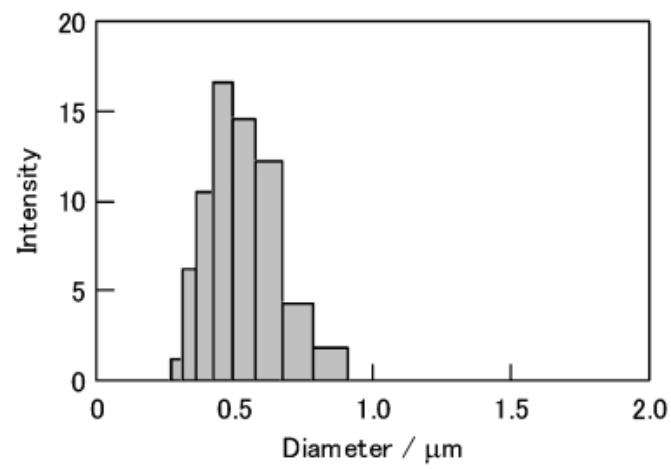

Fig. 3. $\mathrm{La}_{0.8} \mathrm{Sr}_{0.2} \mathrm{Co}_{0.8} \mathrm{Fe}_{0.2} \mathrm{O}_{3-\delta}$ powder distribution.

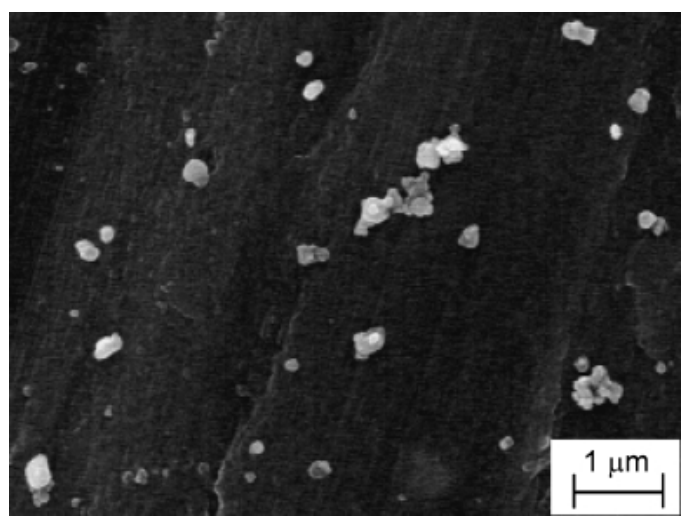

Fig. 4. SEM photograph of $\mathrm{La}_{0.8} \mathrm{Sr}_{0.2} \mathrm{Co}_{0.8} \mathrm{Fe}_{0.2} \mathrm{O}_{3-\delta}$ particles.

where $v / E\left[\mathrm{~m}^{2} / \mathrm{s} \cdot \mathrm{V}\right]$ is the electrophoretic mobility, $v[\mathrm{~m} / \mathrm{s}]$ is the migration speed, $E[\mathrm{~V} / \mathrm{m}]$ is the applied electrical field, $\varepsilon_{\mathrm{r}}[-]$ is the relative dielectric constant of the solution, $\varepsilon_{0}[\mathrm{~F} /$ $\mathrm{m}]$ is the dielectric constant in a vacuum, $\eta\left[\mathrm{N} \cdot \mathrm{s} / \mathrm{m}^{2}\right]$ is the viscosity of the solution, and $\zeta[\mathrm{V}]$ is the zeta potential of solid particles. Commercial methanol $(\mathrm{MeOH})$, ethanol (EtOH), 1-propanol (1-PrOH) and 2-propanol (2-PrOH) were used as the dispersion solvents without pre-treatment. Approximately $0.3 \%$ of water was contained in these alcohols. ${ }^{19)}$ Table 1 shows the physical properties of the promising solvents for the EPD bath, viscosity, and relative dielectric constant of the various solutions. ${ }^{20)}$ All of these solvents have a high relative dielectric constant and a low viscosity. Table 2 shows the zeta potentials and the elec-
Table 1. Physical Properties of Promising Solvents for the EPD Bath $^{20)}$

\begin{tabular}{ccc}
\hline Alcohols & $\begin{array}{c}\text { Relative dielectric } \\
\text { constant } /-\end{array}$ & $\begin{array}{c}\text { Viscosity } \\
/ \mathrm{mPa} \mathrm{s}\end{array}$ \\
\hline Methanol & 32.63 & 0.61 \\
Ethanol & 24.55 & 1.19 \\
1-Propanol & 20.33 & 2.20 \\
2-Propanol & 19.92 & 2.39 \\
\hline
\end{tabular}

Table 2. Zeta Potential and Electrophoretic Mobility of $\mathrm{La}_{0.8} \mathrm{Sr}_{0.2}$ $\mathrm{Co}_{0.8} \mathrm{Fe}_{0.2} \mathrm{O}_{3-\delta}$ Particles

\begin{tabular}{ccc}
\hline Alcohols & $\begin{array}{c}\text { Zeta potential } \\
/ \mathrm{mV}\end{array}$ & $\begin{array}{c}\text { Electrophoretic mobility } \\
/ \mathrm{cm}^{2} \mathrm{~V}^{-1} \mathrm{~s}^{-1}\end{array}$ \\
\hline Methanol & 39.1 & $3.81 \times 10^{-2}$ \\
Ethanol & 23.2 & $3.05 \times 10^{-2}$ \\
1-Propanol & 27.9 & $1.69 \times 10^{-2}$ \\
2-Propanol & 1.4 & $6.38 \times 10^{-3}$ \\
\hline
\end{tabular}

trophoretic mobilities. The zeta potentials of the LSCF powder dispersed in $\mathrm{MeOH}$, EtOH and 1-PrOH were 39.1, 23.2 and $27.9 \mathrm{mV}$, respectively. On the other hand, the zeta potential of the LSCF powder dispersed in 2-PrOH was 1.4 $\mathrm{mV}$. This value is quite low. However, we will not discuss the details of these results in the absence of fundamental data. Moreover, it was found that the LSCF particle migrates to the cathode, because the zeta potential of LSCF was positive based on the result in Table 2. The suspension that has a high zeta potential shows a good dispersibility because these particles have a high repulsive force between each other. Therefore, it was considered that the LSCF powder dispersed in $\mathrm{MeOH}$ showed the highest dispersibility, because it showed the highest zeta potential $(39.1 \mathrm{mV})$.

The results of the electrophoretic mobilities were similar to the result of the zeta potentials. The electrophoretic mobility of the LSCF powder dispersed in $\mathrm{MeOH}, \mathrm{EtOH}$ and 1-PrOH were $3.81 \times 10^{-2}, 3.05 \times 10^{-2}$ and $1.69 \times 10^{-2} \mathrm{~cm}^{2} \cdot \mathrm{V}^{-1} \mathrm{~s}^{-1}$, respectively. On the other hand, the electrophoretic mobility of the LSCF powder dispersed in $2-\mathrm{PrOH}$ was $6.38 \times 10^{-3}$ $\mathrm{cm}^{2} \cdot \mathrm{V}^{-1} \mathrm{~s}^{-1}$. This value is quite low. The electrophoretic mobility of the charged particles is proportional to the dielectric constant and inversely proportional to the viscosity of the solvent. The migrating speed of the LSCF particle is influenced by the applied voltage. For that reason, it is considered that the comparably high zeta potential and high electrophoretic mobility are better for the EPD bath. Here, the LSCF powder dispersed in the $\mathrm{MeOH}$ suspension was selected for the EPD bath.

\subsection{EPD on the stainless steel substrate}

During the initial investigation, a stainless steel substrate was used as the deposition substrate, the EPD bath consisted of $10 \mathrm{~g} / \mathrm{L}$ of LSCF powder in the alcohols, and the applied voltage was $100 \mathrm{~V}$. For $\mathrm{MeOH}$, the LSCF powder was clearly deposited and the amount of the deposit on the cathode increased with the deposition time as shown in Fig. 5. In this case, a uniform deposition layer was observed. On the other 


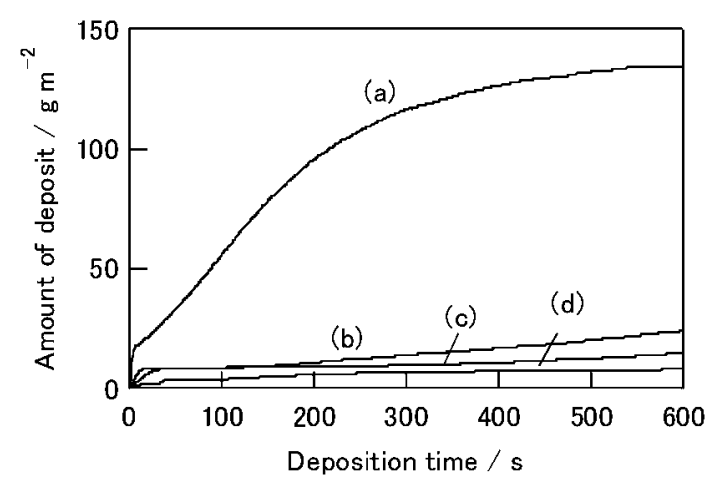

Fig. 5. Relationship between the amount of deposit and deposition time using various alcohol media. (a) Methanol, (b) ethanol, (c) 1propanol and (d) 2-propanol.

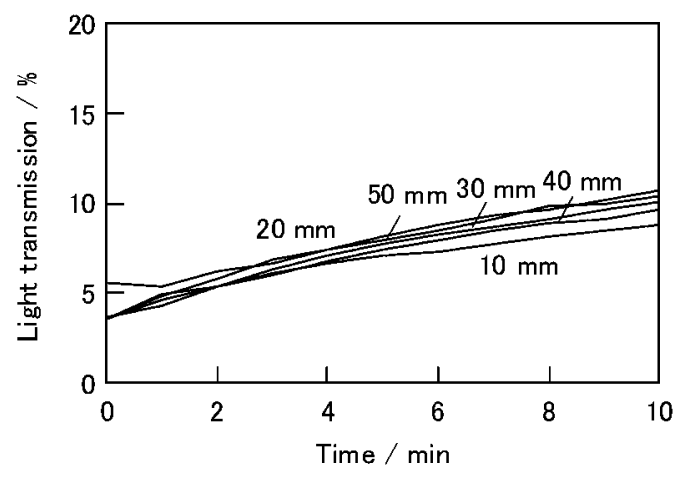

Fig. 6. Dispersing stability of $\mathrm{La}_{0.8} \mathrm{Sr}_{0.2} \mathrm{Co}_{0.8} \mathrm{Fe}_{0.2} \mathrm{O}_{3-\delta}$ particles in methanol medium.

hand, the amounts of the deposits were almost zero using EtOH, 1-PrOH and 2-PrOH compared with the $\mathrm{MeOH}$ bath. It was expected that the amount of the deposit was low for the 2-PrOH bath because the electrophoretic mobility value was low. When using EtOH and 1-PrOH as the dispersing mediums of the LSCF powder, these electrophoretic mobilities were not remarkably low compared to the $\mathrm{MeOH}$ case. However, the amounts of the deposit were quite low compared to $\mathrm{MeOH}$. Although the reason is unknown, we will not discuss the details of these results in the absence of fundamental data. As a result, $\mathrm{MeOH}$ was selected as the dispersing medium of the LSCF powder.

Since the LSCF powder dispersing medium of the EPD bath was determined to be $\mathrm{MeOH}$, the dispersing stability of LSCF in $\mathrm{MeOH}$ was evaluated on the basis of a light transmission measurement. The time vs. concentration for each height of the EPD bath was measured as shown in Fig. 6. For each height, i.e., 10, 20, 30, 40 and $50 \mathrm{~mm}$ from the bottom of the EPD bath, no difference in the concentration was observed. However, these concentrations slightly decreased because the light transmission intensity increased, but not significantly. Consequently, it was considered that the dispersing stability of LSCF in $\mathrm{MeOH}$ was suitable for the EPD bath.

The fundamental EPD property was measured using a stainless steel deposition substrate as shown in Fig. 7. For each applied potential, i.e., 50, 100, 150 and $200 \mathrm{~V} / \mathrm{cm}$, the amount of the deposit increased up to $3 \mathrm{~min}$, then only slowly increased. The deposition surface was quite uniform at less than $100 \mathrm{~V} / \mathrm{cm}$, but it is difficult to prepare a uniform coating over

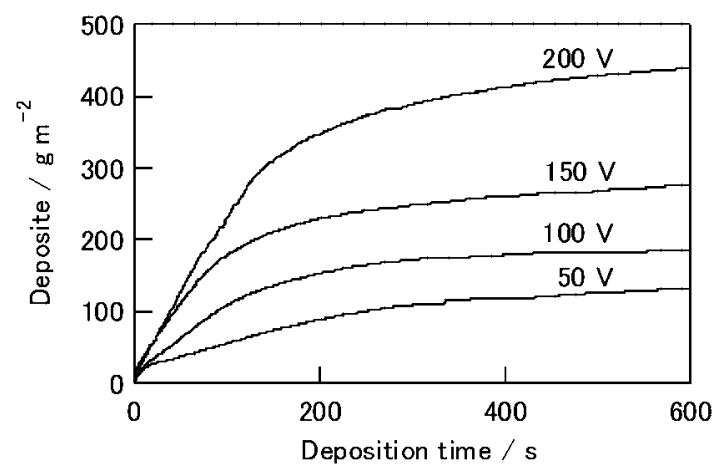

Fig. 7. Relationship between the amount of deposit and deposition time on stainless steel cathode using $\mathrm{MeOH}$ bath.

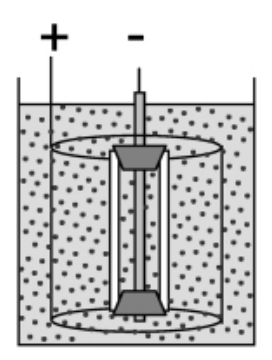

(a)

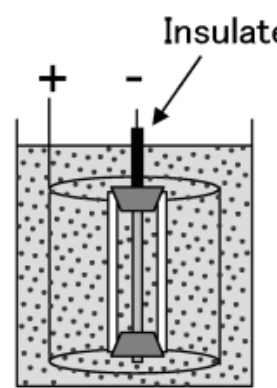

(b)

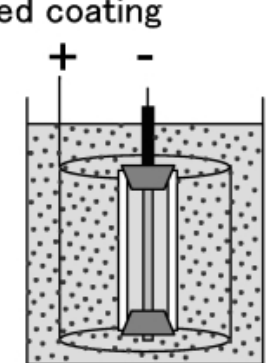

(c)
Fig. 8. Designed cell configurations of EPD using porous alumina tube. (a) EPD bath in the tube, cathode non-coated by an insulated film, (b) EPD bath in the tube, cathode coated by an insulated film and (c) methanol in the tube, cathode coated by an insulated film.

$200 \mathrm{~V} / \mathrm{cm}$. It was found that the EPD of the LSCF powder was suitable for the applied potential of less than $100 \mathrm{~V} / \mathrm{cm}$ and sufficient for a deposition time of less than $10 \mathrm{~min}$.

3.4 EPD on the porous alumina tube

The stainless steel rod as a cathode was placed in the alumina tube, because the porous alumina tube did not have a good electronic conductivity. Figure 8 shows three types of designed cells. The inside of the porous alumina tube was filled with the EPD bath as shown Figs. 8 (a) and (b). On the other hand, the inside of the porous alumina tube was filled with $\mathrm{MeOH}$ as in Fig. 8(c). In addition, the stainless steel rod cathodes were not in contact with the EPD bath in (b) and (c), because these were coated by an insulating film (a heat shrinkable tube of fluororesin), although the stainless steel rod cathodes were in contact with the EPD bath in (a). The deposition amount for these designed cells were measured as shown in Fig. 9. Here, a porous mullite tube was used in the initial investigation to determine the cell structure. The tube diameter and length were the same as the alumina tube but the average pore size was ca. $2 \mu \mathrm{m}$ and the porosity was $28 \%$. From this result, the deposition behavior of the designed cell (a) was found to be unstable. In this case, deposition of the LSCF was observed in the porous alumina tube and on the untreated cathode part. It is considered that the non-uniform deposition was caused by the non-uniformity of the electrical field. For the designed cells (b) and (c), the deposition behaviors were almost the same and a uniform coating was obtained. It seemed that the electrical field was uniform because the active cathode was only inside the porous alumina tube. However, the deposition 
of LSCF inside the porous alumina tube was observed in cell (b). On the other hand, LSCF was deposited only on the outside of the porous alumina tube in cell (c). Based on these results, designed cell (c) was suitable for the EPD using nonelectronically conductive porous ceramic tubes.

A thin coating, such as $20 \mu \mathrm{m}$, was the target for the coating thickness. For example, a thickness less than $20 \mu \mathrm{m}$ is required when the oxygen permeation membrane is assumed. The density of the described LSCF particles is $6.73 \mathrm{~g} / \mathrm{cm}^{3}$. In general, the porosity of the as-deposited layer is approximately $40 \%$. Therefore, for the fabrication of a $20 \mu \mathrm{m}$ thick coating, the amount of the deposit is required to be approximately $200 \mathrm{~g} /$ $\mathrm{m}^{2}$. Figure 10 shows the relationship between the amount of the deposit and deposition time for each applied potential such as 25, 50, 75 and $100 \mathrm{~V}$. The cell configuration of Fig. 8(c) was used. Uniform coatings were obtained for each condition. For the applied voltage of $100 \mathrm{~V}$ and a deposition time of 10 $\mathrm{min}$, an approximate $20 \mathrm{mg} / \mathrm{cm}^{2}$ deposit was obtained.

Figure 11 shows a photograph of this sample. Figure 11 (a) is the fabricated tubular LSCF membrane after sintering at $1500^{\circ} \mathrm{C}$ for $5 \mathrm{~h}$ in air. Figures 11 (b) and (c) are the cross sec-

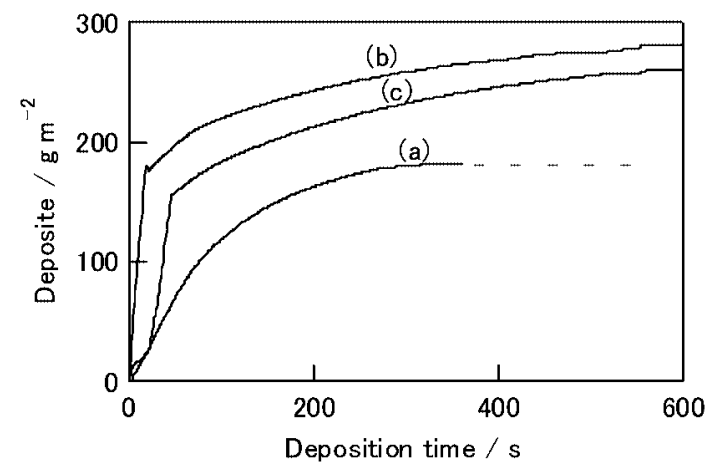

Fig. 9. Relationship between the amount of the deposit and cell configuration on porous mullite substrates. (a) EPD bath in the tube, cathode non-coated by an insulated film, (b) EPD bath in the tube, cathode coated by an insulated film and (c) methanol in the tube, cathode coated by an insulated film. tions of the EPD layer and the sintering layer, respectively. The EPD layer was approximately $30 \mu \mathrm{m}$ and the sintering layer was approximately $20 \mu \mathrm{m}$. A dense uniform coating was obtained after the sintering process as shown in Fig. 11 (c). Thus, the fabrication of a controlled thin layer on non-electronic conductive porous materials was successful by EPD. Factors to optimize include the EPD conditions and sintering conditions for the established gas-tight membrane.

\section{Conclusion}

We investigated the possibility and usefulness of preparing a thin and dense ceramic coating on non-electronically conductive porous tubular ceramics using the electrophoretic deposition (EPD) technique. A $\mathrm{La}_{0.8} \mathrm{Sr}_{0.2} \mathrm{Co}_{0.8} \mathrm{Fe}_{0.2} \mathrm{O}_{3-\delta}$ (LSCF)methanol $(\mathrm{MeOH})$ suspension was used as the EPD bath. LSCF particles were positively charged in the $\mathrm{MeOH}$. For the fabrication of uniform EPD layers, the cathode was arranged in a porous alumina tube. The inside of the porous alumina tubes was filled with $\mathrm{MeOH}$ and the cathode does not contact the EPD bath. A $30 \mu \mathrm{m}\left(200 \mathrm{~g} / \mathrm{m}^{2}\right)$ thick uniform LSCF powder coating was obtained by the EPD at $100 \mathrm{~V}$ for $10 \mathrm{~min}$. After sintering it at $1500^{\circ} \mathrm{C}$ for $5 \mathrm{~h}$, a $20 \mu \mathrm{m}$ dense membrane was obtained. EPD was found to be a useful technique for thin coatings with a controlled thickness on porous

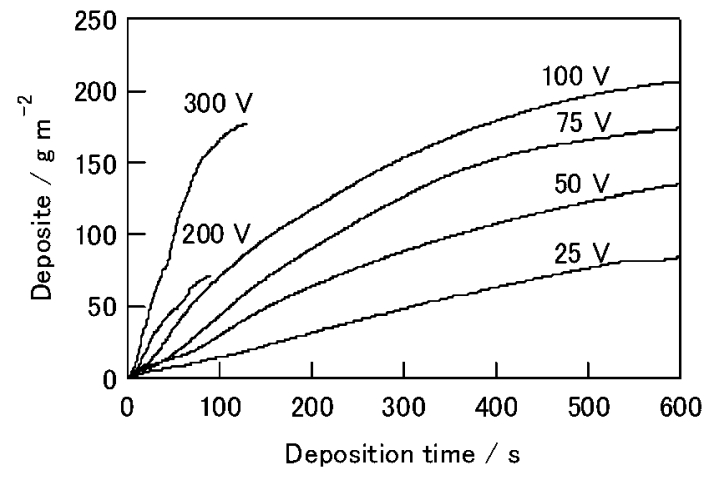

Fig. 10. Relationship between the amount of the deposit and deposition time on porous alumina substrates.

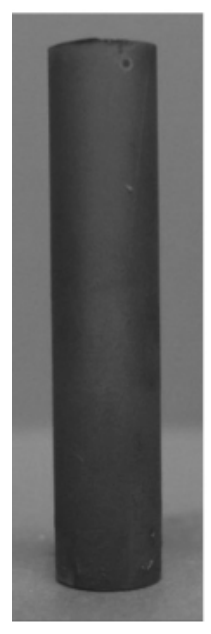

(a)

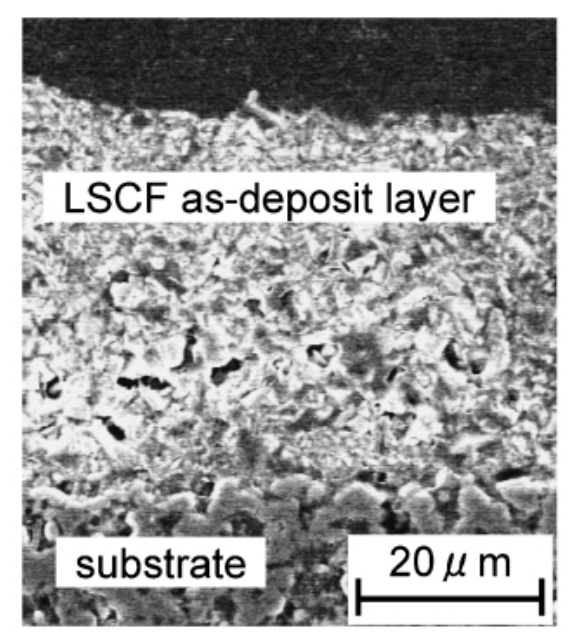

(b)

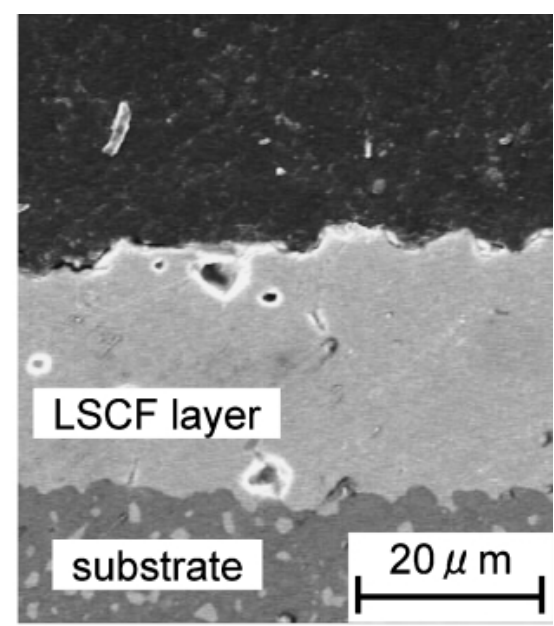

(c)

Fig. 11. Photographs of fabricated tubular $\mathrm{La}_{0.8} \mathrm{Sr}_{0.2} \mathrm{Co}_{0.8} \mathrm{Fe}_{0.2} \mathrm{O}_{3-\delta}$ membrane. (a) Tubular membrane after sintering at $1500^{\circ} \mathrm{C}$ for $5 \mathrm{~h}$, (b) cross section of EPD sample and (c) cross section of sintered sample. 
non-electronically conductive porous tubular substrates.

\section{References}

1) Boccaccini, A. R. and Zhitomirsky, I., Curr. Opin. Solid State Mat. Sci., Vol. 6, pp. 251-260 (2002).

2) Uchikoshi, T., Suzuki, T. S., Okuyama, H., Sakka, Y. and Nicholson, P. S., J. Eur. Ceram. Soc., Vol. 24, pp. 225-229 (2004).

3) Dokou, E., Barteau, M. A., Wagner, N. J. and Lenhoff, A. M., J. Colloid Interface Sci., Vol. 240, pp. 9-16 (2001).

4) Ishihara, T., Sato, K. and Takita, Y., J. Am. Ceram. Soc., Vol. 79, pp. 913-919 (1996).

5) Yamaji, K., Kishimoto, H., Xiong, Y. P., Horita, T., Sakai, N. and Yokokawa, H., Solid State Ionics, Vol. 175, pp. 165-169 (2004).

6) Zhitomirsky, I. and Petric, A., J. Eur. Ceram. Soc., Vol. 20, pp. 2055-2061 (2000).

7) Negishi, H., Sakai, N., Yamaji, K., Horita, T. and Yokokawa, H., J. Electrochem. Soc., Vol. 147, pp. 1682-1687 (2000).

8) Negishi, H., Yamaji, K., Imura, T., Kitamoto, D., Ikegami, T. and Yanagishita, H., J. Electrochem. Soc., Vol. 152, pp. J16-J22 (2005).

9) Matsuda, M., Hosomi, T., Murata, K., Fukui, T. and Miyake, M., Electrochemical and Solid State Letters, Vol. 8, pp. A8-A11 (2005).

10) Diethelm, S., Closset, A., Herle, J. V., McEvoy, A. J. and Nisancioglu, K., Solid State Ionics, Vol. 135, pp. 613-618
(2000).

11) Mazanec, T. J., Solid State Ionics, Vol. 70, pp. 11-19 (1994).

12) Kharton, V. V., Naumovich, E. N. and Nikolaev, A. V., J. Membrane Sci., Vol. 111, pp. 149-157 (1996).

13) Balachandran, U., Dusek, J. T., Sweeney, S. M., Poeppel, R. B., Mieville, R. L., Maiya, P. S., Kleefisch, M. S., Pei, S., Kobylinski, T. P., Udovich, C. A. and Bose, A. C., Am. Ceram. Soc. Bull., Vol. 74, pp. 71-75 (1995).

14) Kharton, V. V., Viskup, A. P., Bochkov, D. M., Naumovich, E. N. and Reut, O. P., Solid State Ionics, Vol. 110, pp. 61-68 (1998).

15) Closset, A., Diethelm, S., Nisancioglu, K., Herle, J. V. and McEvoy, A. J., J. Eur. Ceram. Soc., Vol. 19, pp. 843-846 (1999).

16) Xie, S., Liu, W., Wu, K., Yang, P. H., Meng, G. Y. and Chen, C. S., Solid State Ionics, Vol. 118, pp. 23-28 (1999).

17) Morikawa, H., Mitsui, T., Hamagami, J. and Kanamura, K., Electrochemistry, Vol. 70, pp. 937-939 (2002).

18) Hamagami, J., Kanamura, K., Umegaki, T., Fujiwara, N., Ito, M. and Hirata, S., Trans. Mater. Res. Soc. Jpn., Vol. 27, pp. 77-80 (2002).

19) Takayama, Y., Negishi, H., Nakamura, S., Koura, N., Idemoto, Y. and Yamaguchi, F., J. Ceram. Soc. Japan, Vol. 107, pp. 119-122 (1999).

20) The Chemical Society of Japan, "Kagaku Binran Kisohen," Maruzen, Tokyo (1975) [in Japanese]. 